A.A. Kidov, K. A. Matushkina, K. A. Afrin

\title{
SOME ASPECTS OF CAPTIVE BREEDING OF THE KARELIN'S NEWT, TRITURUS KARELINII STRAUCH, 1870 FROM TALYSH POPULATION
}

Data on reproduction of the Karelin's newt from the Talysh population in captivity are provided. 11 pairs from the Zarbyulyun natural boundary (Astara administrative region, Azerbaijan) were involved in the study. Oviposition was observed between 19 and 90 days after placement of animals into water. Females spawned between January 24 and June 5 at a temperature of $6.0-23.5^{\circ} \mathrm{C}$. The total duration of the oviposition period in different pairs was between 40 and 133 days. Fertility of females during the reproductive period varied from 44 to 2362 eggs, an average daily amount of eggs was 0.6-19.0. The maximum length of the laid egg in the first day after oviposition was $3.8-5.8 \mathrm{~mm}$, the maximum width $-2.4-3.3 \mathrm{~mm}$, diameter of the vitellus: $1.8-2.7 \mathrm{~mm}$. Developmental time estimated from oviposition to hatching was 7-15 days, and larval development from hatching to start of feeding was 5-8 days. During the reproductive period, we obtained 14 to 345 prelarvae from each female, that was $10.3-41.2 \%$ of the laid eggs. The survival of prelarvae from hatching to start of feeding from different spawns was $61.5-100.0 \%$, so that from each female 14 to 328 actively feeding larvae were obtained. Refs 7.

Keywords: Karelin's newt, captive breeding, reproductive biology.

\section{А. А. Кидов, К.А. Матуикина, К.А.Африн}

\section{НЕКОТОРЫЕ АСПЕКТЫ РАЗМНОЖЕНИЯ ТРИТОНА КАРЕЛИНА, TRITURUS KARELINII STRAUCH, 1870 ТАЛЫШСКОЙ ПОПУЛЯЦИИ В ЛАБОРАТОРНЫХ УСЛОВИЯХ}

\author{
Российский государственный аграрный университет - МСХА имени К. А. Тимирязева, \\ Российская Федерация, 127550, Москва, ул. Тимирязевская, 49; \\ kidov_a@mail.ru, matushkinaka@gmail.com,kidov_a@mail.ru
}

Приводятся данные о размножении тритона Карелина из талышской популяции в лабораторных условиях. В исследованиях были задействованы 11 пар из урочища Зарбюлюн (Астаринский административный район, Азербайджан). Икрометание наблюдалось через 19-90 суток после высадки животных в воду. Самки откладывали яйца между 24 января и 5 июня при температуре $6,0-23,5^{\circ} \mathrm{C}$. Общая протяженность периода икрометания у разных пар составляла 40-133 суток. Плодовитость самок за весь репродуктивный период варьировала от 44 до 2362 яиц при среднесуточном значении этого показателя 0,6-19 яиц. Наибольшая длина яйца в первые сутки после откладки составляла 3,8-5,8 мм, наибольшая ширина - 2,4-3,3 мм, диаметр желтка - 1,8-2,7 мм. Длительность развития от откладки яйца до выклева варьировала в пределах 7-15 суток, а от вылупления до перехода на экзогенное питание - от 5 до 8 суток. От каждой самки за весь репродуктивный период были получены от 14 до 345 предличинок, что составило 10,3-41,2\% от отложенных яиц. Выживаемость предличинок от вылупления до начала экзогенного питания у разных самок была равна 61,5-100\%, а всего от каждой самки были получены от 14 до 328 питающихся личинок. Библиогр. 7 назв.

Ключевые слова: тритон Карелина, лабораторное размножение, репродуктивная биология.

The range of the Karelin's newt, Triturus karelinii Strauch, 1870 in its southeastern part is represented by a large isolated plot in the Lenkoran and South-Caspian Lowlands, and on the coastal slopes of the Talysh Mountains in the Northwestern Iran and Southeast of Azerbaijan [1-2]. The majority of the finds of this species are known for lowland and

A.A.Kidov (kidov_a@mail.ru), K.A.Matushkina (matushkinaka@gmail.com), K.A.Afrin (kidov_a@ mail.ru): Russian State Agrarian University - K.A. Timiryazev Moscow Agricultural Academy, 49, ul. Timiryazevskaya, Moscow, 127550, Russian Federation.

( С Санкт-Петербургский государственный университет, 2016 
foothill areas, and only five isolated localities - for Talysh midlands [2-4]. Despite the fact that the Karelin's newt was included in the national Red Data Book of the Republic of Azerbaijan [5], a real measures of its protection are not carried out, and all known finds of this species in Talysh Mountains are located outside the specially protected natural territories [2]. Since 2009 we work on the production of new ponds for breeding of this newt in the Astara District of Azerbaijan, and also we introduce young captive bread animals to these reservoirs [6].

Interestingly, the Karelin's newt from North Caucasian region had lived and were regularly reproduced in the collections of fans of terrarium animals, and in a number of Russian scientific organizations (A. N. Severtsov Institute of Ecology and Evolution RAS, Institute of Cell Biophysics RAS, Moscow Zoo, Sochi National Park) [6-7]. However, a number of aspects of its reproductive biology are known obviously not enough. In particular, contradictory information remains on the duration and conditions of the reproductive period, the fertility of females, the duration of individual stages of embryonic and larval development. We have previously presented initial results of the study of these parameters on a limited number of animals (three pairs) caught in nature before the breeding had started [6].

Here we present further work on reproduction and development of the Karelin's newt from Talysh population, and summarize the results of the captive breeding of animals, which were caught in nature or obtained in the laboratory during captive breeding.

\section{Materials and methods}

The study was carried out in 2014-2015 at the Department of Zoology in the Russian State Agrarian University - K. A. Timiryazev Moscow Agricultural Academy. The experiments involved 11 pairs of the Karelin's newt from the Zarbyulyun Natural Boundary $\left(38^{\circ} 29^{\prime} \mathrm{N}, 48^{\circ} 36^{\prime} \mathrm{E}, 780 \mathrm{~m}\right)$ in Astara District of Azerbaijan. Most of the animals (11 females and 9 males) were captured in nature in 2011-2012, and 2 males were obtained from a captive breeding in 2014. Total body and tail length in females was 136.5-155.2 $\mathrm{mm}$ (average of 143.3 $\pm 2.34 ; \mathrm{SD}=6.61 ; \mathrm{N}=11$ ), and males $-114.6-139.8 \mathrm{~mm}$ (125.2 $\pm 2.97 ; \mathrm{SD}=8.40 ; \mathrm{N}=11)$. The weight of adult animals before placing for reproduction was 6.6-14.4 $\mathrm{g}(11.0 \pm 0.83 ; \mathrm{SD}=2.63 ; \mathrm{N}=11)$ in females and 6.3-11.0 $\mathrm{g}(8.1 \pm 0.56 ; \mathrm{SD}=1.76$; $\mathrm{N}=11$ ) in males.

Before the start of the breeding period adult animals were kept in plastic containers, with sides $39 \times 28 \times 14 \mathrm{~cm}$, filled with soil from the crushed bark of the Siberian larch. Each terrarium was equipped with a Petri dish as a water source. The temperature was maintained at $25-28^{\circ} \mathrm{C}$, and natural light illumination was provided. The animals were fed by the larvae of spotted cricket, Grillus bimaculatus De Geer, 1773, and red manure worm, Eisenia foetida (Savigny, 1826). From January 5, each pair of newts was kept in the same container, but filled with water up to the level of $10 \mathrm{~cm}$ from bottom. As a substrate for oviposition, the Java moss Vesicularia dubyana (Müll. Hal., 1908) was used. Feeding of the adult newts in water was regular at 2-3 times per week basis with larvae big wax moth, Galleria mellonella (Linnaeus, 1758) and red manure worm. Replacement of a half of the water volume was made $2-3$ times a week.

Laid eggs were removed daily and their number was counted. In the first day after oviposition the length and the width of the eggs, and the diameter of the vitellus were 
measured by Vernier caliper with accuracy of $0.1 \mathrm{~mm}$. The keeping of the eggs and prelarvae before they started exogenous feeding was carried out in 0.51 and 5.01 containers, respectively. The duration of time from egg laying to transition of larvae to exogenous nutrition we considered as embryonal period. The length of the body of prelarvae was determined on fixed in $70 \%$ ethanol animals.

\section{Results}

The mating behavior of males was observed at a temperature of $14.5-21.0^{\circ} \mathrm{C}$ (18.2 $\pm 2.35 ; \mathrm{SD}=3.33 ; \mathrm{N}=3)$. Oviposition was observed in 19-90 (56.6 $\pm 7.61 ; \mathrm{SD}=22.84$; $\mathrm{N}=11$ ) days after disembarkation of animals into water. The first cases of egg-laying were observed at water temperatures of $11.5-21.0^{\circ} \mathrm{C}(14.7 \pm 0.86 ; \mathrm{SD}=2.59 ; \mathrm{N}=11)$. Overall, spawning occurred within a temperature range from 6.0 to $23.5^{\circ} \mathrm{C}(16.7 \pm 0.13 ; \mathrm{SD}=3.30$; $\mathrm{N}=623$ ). All clutches of eggs were between January 24 and June 5 . The total duration of the spawning season in different females ranged from 40 to 133 days $(79.8 \pm 10.31$; $\mathrm{SD}=30.93 ; \mathrm{N}=11)$. The total fecundity of females over the entire reproductive period was in the range 44-2362 eggs $(661 \pm 227.2 ; \mathrm{SD}=681.7 ; \mathrm{N}=11)$, and the average daily value of this characteristic was $0.6-19.0$ eggs $(7.3 \pm 1.61 ; \mathrm{SD}=4.85 ; \mathrm{N}=11)$. Maximum mean daily fecundity of different females was 5-40 eggs $(25.5 \pm 3.86 ; \mathrm{SD}=11.58 ; \mathrm{N}=11)$. The greatest interval between the laying of eggs by different females varied in the range of 2-41 days $(8.2 \pm 3.89 ; \mathrm{SD}=11.67 ; \mathrm{N}=11)$. The maximum length of egg in the first day after the oviposition was $3.8-5.8 \mathrm{~mm}(4.6 \pm 0.04 ; \mathrm{SD}=0.39 ; \mathrm{N}=98)$, the maximum width $2.4-3.3 \mathrm{~mm}(2.7 \pm 0.03 ; \mathrm{SD}=0.28 ; \mathrm{N}=98)$, diameter of a vitellus $-1.8-2.7 \mathrm{~mm}(2.1 \pm 0.01$; $\mathrm{SD}=0.14 ; \mathrm{N}=98)$. The latest cases of oviposition for different females were noted at a water temperature of $18.0-22.5^{\circ} \mathrm{C}(19.8 \pm 0.71 ; \mathrm{SD}=2.12 ; \mathrm{N}=11)$. Different animals during the breeding period could both lose or increase their weight: females by the end of the spawning season had $80.5-127.7 \%(98.9 \pm 4.76 ; \mathrm{SD}=15.04 ; \mathrm{N}=11)$ in comparison to the weight they had before disembarkation in water, and males - 98.2-119.0\% (103.6 \pm 3.49 ; $\mathrm{SD}=11.02 ; \mathrm{N}=11)$. Development duration estimated as oviposition to hatching was $7-15$ days $(11.3 \pm 0.21 ; \mathrm{SD}=1.48 ; \mathrm{N}=148)$, and from hatching to start of feeding - from 5 to 8 days $(6.9 \pm 0.14 ; \mathrm{SD}=1.02 ; \mathrm{N}=99)$. The total duration of embryonic development from the oviposition to start of exogenous feeding was $14-22$ days $(17.0 \pm 0.20 ; \mathrm{SD}=1.39 ; \mathrm{N}=140)$. The incubation of eggs was characterized by a low percentage of developing embryos. So, from each female for the entire reproductive period we obtained only 14 to 345 prelarvae (167.5 $\pm 36.72 ; \mathrm{SD}=116.13 ; \mathrm{N}=11)$, that was 10.3 to $41.2 \%(33.33 \pm 2.72 ; \mathrm{SD}=8.60 ; \mathrm{N}=11)$ of the laid eggs. The survival of prelarvae from hatching to start of exogenous feeding for different females was 61.5-100.0\% (87.6 \pm 3.33 ; $\mathrm{SD}=10.54 ; \mathrm{N}=11)$, and from each female we received from 14 to 328 feeding larvae $(149.5 \pm 33.85 ; \mathrm{SD}=107.05 ; \mathrm{N}=11)$.

\section{References}

1. Alekperov A.M. Zemnovodnye i presmykaiushchiesia Azerbaidzhana [Amphibians and Reptiles of Azerbaijan]. Baku, 1978, 264 p. (In Russian)

2. Litvinchuk S. N., Borkin L. J. Evoliutsiia, sistematika i rasprostranenie grebenchatykh tritonov (Triturus cristatus complex) na territorii Rossii i sopredel'nykh stran [Evolution, systematics and distribution of crested newts (Triturus cristatus complex) in Russia and adjacent countries]. St. Petersburg, 2009, 592 p. (In Russian)

3. Kidov A. A., Matushkina K. A. O novykh nakhodkakh tritona Karelina (Triturus karelinii Strauch, 1870) na Kavkaze [About new cases of the Karelin's newt (Triturus karelinii Strauch, 1870) on Caucasus]. 
Sovremennaia gerpetologiia: problemy i puti ikh resheniia [Modern herpetology: problems and ways of their solutions], St. Petersburg, 2013, pp. 94-95. (In Russian)

4. Kidov A. A., Matushkina K. A. Postlarval'nyi rost tritona Karelina, Triturus karelinii (Strauch, 1870) (Amphibia, Caudata: Salamandridae) v Talyshskikh gorakh [Post-larval growth of the Karelin's newt, Triturus karelinii (Strauch, 1870) (Amphibia, Caudata: Salamandridae) in Talysh Mountains]. Aktual'nye problemy ekologii i sokhraneniia bioraznoobraziia Rossii i sopredel'nykh stran [Actual problems of ecology and preservation of biodiversity in Russia and adjacent countries]. Vladikavkaz, 2012, vol. 8, pp. 46-50. (In Russian)

5. Qəniyev E. F. (Ganiyev E. F.) Karelin tritonu Triturus karelinii Strauch, 1870 [Karelin's newt Triturus karelinii Strauch, 1870]. Azabaycan Respublikasinin Qirmizi Kitabi. Nadir va nasli kəsilməktə olan fauna növlari. 2-ci naşr [Red Data Book of Azerbaijan Republic. Second edition], Baku, 2013, pp. 220-221. (In Azerbaijani)

6. Kidov A.A., Matushkina K.A., Afrin K.A. Pervye rezul'taty laboratornogo razmnozheniia i reintroduktsii tritona Karelina, Triturus karelinii Strauch, 1870 talyshskoi populiatsii [The first results of captive breeding and reintroduction of the Karelin's newt, Triturus karelinii Strauch, 1870 from Talysh population]. Vestnik Buriatskogo gosudarstvennogo universiteta [Vestnik of Buryat State University], 2015, issue S4, pp. 81-89. (In Russian)

7. Uteshev V.K., Kidov A. A., Kaurova S. A., Shishova N. V. Pervyi opyt razmnozheniia tritona Karelina, Triturus karelinii (Strauch, 1870) s ispol'zovaniem oplodotvoreniia ikry urinal'noi spermoi [First experience of reproduction of the Karelin's newt, Triturus karelinii (Strauch, 1870) with urinal sperm use for eggs fertilization]. Vestnik Tambovskogo universiteta. Seriia Estestvennye i tekhnicheskie nauki [Vestnik of Tambov University. Natural and technical sciences], 2013, vol. 18, issue 6-1, pp. 3090-3092. (In Russian)

For citation: Kidov A. A., Matushkina K. A., Afrin K. A. Some aspects of captive breeding of the Karelin's Newt, Triturus Karelinii Strauch, 1870 from Talysh population. Vestnik of Saint Petersburg University. Series 3. Biology, 2016, issue 3, pp. 54-57. DOI: 10.21638/11701/spbu03.2016.310

Authors information:

Kidov Artem A. - PhD, Associate Professor

Matushkina Kseniya A. - Assistant

Afrin Kirill A. - Chief of Zoological Museum 